\title{
KEBIJAKAN PEMBANGUNAN PERUMAHAN PEMERINTAH KOTA SURABAYA DAN KONSISTENSI TERHADAP PEMANFAATAN LAHAN
}

\author{
Deasy Arieffiani
}

\begin{abstract}
Abstrak
Kebijakan Pemerintah Kota Surabaya dalam pemanfaatan lahan dan perwujudan pembangunan pemukiman yang baik, maka beberapa keputusan dalam pembangunan rusun dan apartemen memiliki efektifitas yang melibatkan pihak pelaku dan lingkungan. Efektifitas dari kebijakan pemerintah dalam membangn rusun dan apartemen ini terwujud karena memenuhi kebijakan yang melibatkan publik dalam segala tahap, realistic, transparan, jelas tolak ukurnya, jelas target atau sasarannya, jelas dasar hukumnya, dan kebijakan yang tidak tumpang tindih. Perencanaan embangunan ini sebagai perwujudan keputusan pemerintah yang tertuang dalam Peraturan Walikota Surabaya Nomor 46 Tahun 2013 Tentang Rencana Kerja Pembangunan Daerah (RKPD) Kota Surabaya Tahun 2014.
\end{abstract}

Kata kunci: Efektifitas, Kebijakan Publik, Pembangunan Rusun dan Apartemen

Jumlah penduduk di Indonesia semakin meningkat setiap tahunnya, oleh karena itu Pemerintah dipandang sangat penting untuk membuat aturan yang tegas dalam mengatur dan menjamin kesejahteraan rakyat. Sebagai kota terpadat kedua setelah ibukota Jakarta, kota Surabaya merupakan salah satu kota yang memiliki jumlah penduduk yang cukup besar. Adapun berbagai kebijakan Pemerintah kota Surabaya telah dibuat dan diharapkan terlaksana dengan baik. Kebijakan tersebut meliputi model kelembagaan, kelompok, elit, rasional, incremental, dan sistem. Model kebijakan ini bertujuan untuk memenuhi kebutuhan dan kesejahteraan masyarakat kota. Setiap peraturan ditetapkan dengan memiliki tujuan yang pasti dan dipandang memiliki faktor kemanfaatan bagi seluruh aspek kehidupan. Dengan demikian definisi dari kebijakan publik dapat didefinisikan sebagai aturan yang ditetapkan dan dilakukan atau tidak dilakukan oleh pemerintah yang dapat tertuang dalam peraturan perundang-undangan atau dalam policy statement yang berbentuk pidato-pidato dan wacana yang diungkapkan pejabat politik dan pejabat pemerintah yang segera ditindaklanjuti dengan program-program dan tindakan pemerintah (Edwards \& Sharkansky, 2008).

Dalam mengatur sebuah Negara sebagai lingkup yang luas diperlukan pengaturan sistem pemerintahan setiap kota yang ada di suatu Negara. Negara 
Indonesia tidak dapat berdiri sendiri tanpa adanya pembangunan yang sukses dari setiap kota di tiap pulau dari sabang sampai merauke. Hal yang tidak dapat dilepaskan adalah permasalahan-permasalahan yang ada di setiap kota yang memiliki ciri khas masing-masing, sebagai contoh masalah pengaturan pembuangan sampah kota A berbeda dengan kota B. Hal tersebut adalah salah satu masalah yang kecil dan masih terdapat berbagai macam permasalahan yang dihadapi oleh pemerintah kota, salah satu masalah pembangunan yang sedang dibicarakan oleh berbagai kalangan adalah terkait dengan masalah kepadatan penduduk dan perumahan. Sebagai kebutuhan primer setiap insan manusia, pemerintah wajib untuk mengatur masyarakatnya dan memberikan solusi dari masalah pertambahan penduduk dan perpindahan penduduk daerah ke kota.

Untuk memberikan solusi dari masalah mobilitas penduduk, maka beberapa tahun ini telah dibangun banyak rusun dan apartemen dengan harga yang cukup terjangkau sehingga tidak hanya masyarakat kaya raya yang dapat memiliki apartemen tetapi juga masyarakat ekonomi menengah juga dapat membeli apartemen sebagai pengganti kepemilikan rumah karena dipandang rumah memiliki harga yang sangat mahal. Kebijakan pemerintah dalam memberikan perijinan pembangunan rusun dan apartemen merupakan wujud dari solusi untuk mengatasi masalah penduduk yang semakin meningkat. Oleh karena lahan tanah di Surabaya semakin menyempit, sehingga rusun dan apartemen dapat mengurangi pemakaian lahan. Adapun terdapat keterkaitan yang erat antara pertambahan masyarakat yang berkeluarga atau berstatus menikah dengan tuntutan kepemilikan tempat tinggal. Hal ini dalah proses kehidupan dimana masyarakat telah berkembang baik dari segi pendidikan, ekonomi dan spiritual. Kemajuan ini menuntut pemerintah untuk menyediakan pembangunan sarana dan prasarana yang lebih baik.

Pembangunan rusun dan apartemen juga menjawab permasalahan perpindahan penduduk daerah ke kota. Beberapa tujuan perpindahan penduduk dari desa ke kota antara lain lulusan SMA melanjutkan kuliah di Universitas, seorang pegawai mutasi kerja ke kota, pernikahan, dan perdagangan, penyebaran agama, dan pencarian nafkah yang lebih baik. Seorang karyawan swasta yang telah berpindah ke kota untuk tujuan tugas pekerjaan, maka membutuhkan tempat tinggal. Seorang 
pimpinan perusahaan berpindah ke Surabaya untuk tujuan perluasan marketing produk dagangannya. Motif dan tujuan inilah yang mendorong masyarakat menempati kota Surabaya. Sebagai tambahan, pemerintah memprediksikan bahwa lahan tanah di kota Surabaya dalam jangka waktu 5 sampai 10 tahun kedepan akan menyempit karena dalam kurun waktu 10 tahun ini terdapat pembangunan perumahan yang cukup besar baik di Surabaya pusat, utara, selatan, barat dan timur. Hampir di setiap tempat akan diprediksi sulit menemukan lahan tanah. Berdasarkan definisi -definisi kebijakan publik yang dipaparkan di atas, maka kebijakan publik memiliki konsep-konsep sebagai berikut seperti yang dikemukakan oleh Taufik, 2002:

(1). Kebijakan publik berisi tujuan, nilai-nilai, dan praktik/pelaksanaannya.

(2). Kebijakan publik tersebut dibuat oleh badan pemerintah, bukan organisasi swasta.

(3). Kebijakan publik tersebut menyangkut pilihan yang dilakukan atau tidak dilakukan oleh pemerintah.

Dari poin - poin di atas maka kita bisa menarik benang merah dari definisi kebijakan publik dalam Lampiran 1 Peraturan Menteri Pendayagunaan Aparatur Negara Nomor PER/04/M.PAN/4/2007 tentang Pedoman Umum Formulasi, Implementasi, Evaluasi Kinerja, dan Revisi Kebijakan Publik di Lingkungan Lembaga Pemerintah Pusat dan Daerah. Dalam Peraturan Menteri ini, kebijakan 16 publik adalah keputusan yang dibuat oleh pemerintah atau lembaga pemerintahan untuk mengatasi permasalahan tertentu, untuk melakukan kegiatan tertentu atau untuk mencapai tujuan tertentu yang berkenaan dengan kepentingan dan manfaat orang banyak. Dalam Peraturan Menteri tersebut, kebijakan publik mempunyai 2 (dua) bentuk yaitu peraturan yang terkodifikasi secara formal dan legal, dan pernyataan pejabat publik di depan publik. Menurut Subarsono (2005:3) kebijakan publik dapat berupa Undang-Undang, Peraturan Pemerintah, Peraturan Pemerintah Provinsi, Peraturan Pemerintah Kota/Kabupaten, dan Keputusan Walikota/Bupati. Berdasarkan Peraturan Menteri ini, pernyataan pejabat publik juga merupakan bagian kebijakan publik. Hal ini dapat dipahami karena pejabat publik adalah salah satu aktor kebijakan yang turut berperan dalam implementasi kebijakan itu sendiri. 
Kebijakan pemerintah dalam melaksanankan pembangunan Apartemen memiliki tujuan dan nilai-nilai positif. Pembangunan ini bukan semata untuk tujuan keuntungan perusahaan swasta ataupun badan usaha properti, melainkan perijinan dilakukan untuk kesejahteraan masyarakat luas, yaitu:

(1). Pemanfaatan lahan dengan bijak

(2). Mewadahi masyarakat dengan kehidupan yang lebih ekonomis dan terjangkau

(3). Proses kepemilikan tempat tinggal yang lebih mudah.

(4). Mobilisasi dari satu tempat ke tempat lain yang lebih cepat.

(5). Pemerataan hak kepemilikan tempat tinggal.

Di berbagai tempat belahan dunia, baik Negara berkembang maupun maju seperti Jepang, Singapura, dan Taiwan telah memusatkan pembangunan tempat tinggal yaitu Apartemen, selain dinilai bahwa Negara-negara tersebut memiliki lahan/ daratan yang tidak cukup luas, tetapi dengan adanya dorongan kemajuan teknologi maka telah banyak dibangun Apartemen. Pemusatan pembangunan Apartemen di Negara tersebut merupakan hasil dari kebijakan pemerintah Negara yang terkait. Dengan demikian definisi dari kebijakan publik dapat berarti keputusan yang bijak yang dirumuskan melalui pemikiran dan pertimbangan yang matang sehingga tercipta tindakan yang bijak dan memperhatikan lingkungan. Menurut Thomas R. Dye dalam Dunn (2000: 110) terdapat tiga elemen kebijakan yang membentuk sistem kebijakan. Dye menggambarkan ketiga elemen kebijakan tersebut sebagai kebijakan publik/public policy, pelaku kebijakan/ policy stakeholders, dan lingkungan kebijakan/policy environment.

\section{Gambar 1. Tiga Elemen Sistem Kebijakan}

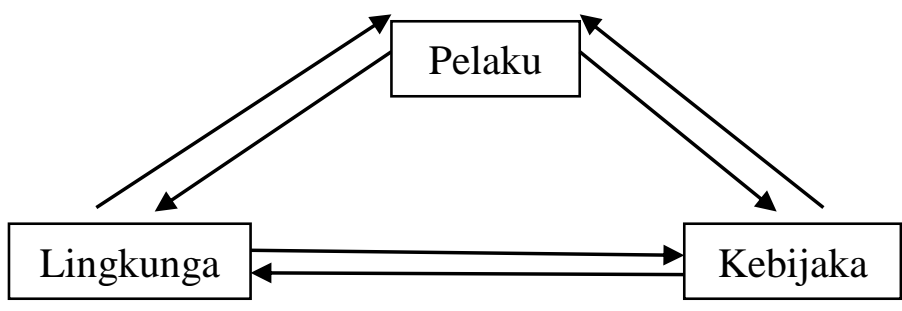


Gambar diatas menyimpulkan bahwa masyarakat sebagai pelaku memiliki hubungan yang saling berpengaruh dengan lingkungan dan pembentukan kebijakan. Ketika masayarakat melakukan suatu tindakan terhadap lingkungan baik yang berakibat positif maupun negatif, maka kebijakan pengaturan dan pengendalian akan terbentuk. Sebagai contoh adalah kebijakan pemerintah untuk melarang dengan keras pembakaran hutan dan penebangan hutan di Kalimantan demi perlindungan manusia dan penyediaan oksigen bagi makhluk hidup. Demikian juga dengan lingkungan memberikan suatu akibat buruk bagi pelaku, maka kebijakan perlindungan akan ditetapkan. Sebagai contoh yaitu perlindungan terhadap korban bencana gunung meletus. Tiga elemen sistem kebijakan tidak dapat dipisahkan karena saling terkait. Kebijakan pemerintah terlahir dari pelaku dan lingkungan dan pemerintah memperhatikan kesejahteraan pelaku yaitu masyarakat dan lingkungan hidup untuk membentuk suatu kebijakan.

Kota Surabaya sebagai kota terbesar kedua, Surabaya terbagi menjadi sejumlah area/kawasan strategis antara lain:

1. Perumahan vertikal baik berupa rumah susun (sederhana) maupun apartemen atau kondominium (mewah).

2. Perumahan real estate yang tersebar di kawasan barat, timur dan selatan kota.

3. Perumahan kampung yang terkonsentrasi di area pusat kota.

4. Area untuk kegiatan jasa dan perdagangan yang terkonsentrasi di kawasan pusat kota dan sebagian di area perumahan yang berkembang di kawasan barat dan timur kota.

5. Area untuk kegiatan industri dan pergudangan terkonsentrasi di kawasan pesisir utara dan kawasan

selatan kota yang berbatasan dengan wilayah Kabupaten Gresik dan Sidoarjo.

6. Wilayah pesisir yang dimanfaatkan untuk perumahan pesisir (kampung nelayan), tambak garam dan ikan, pergudangan militer, industri kapal, pelabuhan, wisata serta jalan yang menghubungkan Kota Surabaya dan Pulau Madura (Jembatan Suramadu).

7. Ruang laut Surabaya selain dimanfaatkan untuk kegiatan pelayaran baik interinsulair maupun 
internasional, juga dikembangkan untuk kegiatan penangkapan ikan tradisional dan wisata pantai di Kenjeran dan sekitarnya.

Sebagaimana yang tertuang diatas bahwa pembangunan kota Surabaya juga mengembangkan bidang perumahan, seperti rumah susun, apartemen, dan kondominium, maka penelitian memusatkan analisis pada efektifitas kebijakan pemerintah dalam mengatur pembangunan rusun dan apartemen sebagai solusi pertambahan penduduk di kota Surabaya. Pembangunan ini diharapkan memiliki proses kebijakan public yaitu penyusunan agenda, formulasi kebijakan, adopsi kebijakan, implementasi kebijakan, dam penilaian kebijakan (Dunn, W, 2003).

Jumlah penduduk Kota Surabaya sampai dengan tahun 2012 adalah sebanyak 3.125.576. jiwa. Jumlah penduduk terbanyak berada di Kecamatan Tambaksari yaitu 242.735 jiwa. Sedangkan jumlah penduduk yang paling sedikit terdapat di Kecamatan Bulak, yaitu 41.742 jiwa. Komposisi penduduk kota Surabaya pada tahun 2012 berdasarkan jenis kelamin meliputi 1.566 .072 jiwa penduduk laki-laki $(50,105 \%)$ dan 1.559 .504 jiwa penduduk perempuan $(49,895 \%)$ sebagaimana yang disajikan pada tabel 1.

Tabel 1. Jumlah Penduduk Kota Surabaya Berdasarkan Jenis Kelamin Tahun 2012

\begin{tabular}{|l|l|l|l|l|}
\hline \multirow{2}{*}{ No } & \multirow{2}{*}{ Kecamatan } & \multicolumn{2}{|c|}{ Jenis kelamin } & \multirow{2}{*}{$\begin{array}{c}\text { Jumlah } \\
\text { (Jiwa) }\end{array}$} \\
\cline { 3 - 4 } & & \multicolumn{1}{|c|}{ Laki-laki } & \multicolumn{1}{c|}{ Perempuan } & \\
\hline 1 & Karang Pilang & 38.924 & 38.298 & 77.222 \\
\hline 2 & Wonocolo & 42.436 & 42.381 & 84.817 \\
\hline 3 & Rungkut & 54.048 & 53.906 & 107.954 \\
\hline 4 & Wonokromo & 96.122 & 96.131 & 192.253 \\
\hline 5 & Tegalsari & 57.942 & 58.322 & 116.264 \\
\hline 6 & Sawahan & 114.826 & 115.268 & 230.094 \\
\hline 7 & Genteng & 33.784 & 34.588 & 68.372 \\
\hline 8 & Gubeng & 76.230 & 77.924 & 154.154 \\
\hline 9 & Sukolilo & 55.700 & 55.568 & 111.268 \\
\hline 10 & Tambak Sari & 121.252 & 121.483 & 242.735 \\
\hline 11 & Simokerto & 53.190 & 53.569 & 106.759 \\
\hline 12 & Pabean Cantian & 46.556 & 46.056 & 92.612 \\
\hline 13 & Bubutan & 57.695 & 57.564 & 115.259 \\
\hline 14 & Tandes & 48.843 & 48.678 & 97.521 \\
\hline 15 & Krembangan & 65.183 & 64.420 & 129.603 \\
\hline 16 & Semampir & 103.414 & 102.025 & 205.439 \\
\hline 17 & Kenjeran & 76.722 & 75.189 & 151.911 \\
\hline & & & & \\
\hline
\end{tabular}




\begin{tabular}{|l|l|l|l|l|}
\hline 18 & Lakar Santri & 28.083 & 27.623 & 55.706 \\
\hline 19 & Benowo & 27.586 & 27.324 & 54.910 \\
\hline 20 & Wiyung & 34.670 & 34.123 & 68.793 \\
\hline 21 & Dukuh Pakis & 31.723 & 31.443 & 63.166 \\
\hline 22 & Gayungan & 24.630 & 24.456 & 49.086 \\
\hline 23 & Jambangan & 25.095 & 24.545 & 49.640 \\
\hline 24 & Tenggilis Mejoyo & 28.709 & 28.717 & 57.426 \\
\hline 25 & Gunung Anyar & 26.880 & 26.712 & 53.592 \\
\hline 26 & Mulyorejo & 43.820 & 44.303 & 88.123 \\
\hline 27 & Sukomanunggal & 52.880 & 52.549 & 105.429 \\
\hline 28 & Asemrowo & 23.445 & 22.177 & 45.622 \\
\hline 29 & Bulak & 20.981 & 20.761 & 41.742 \\
\hline 30 & Pakal & 24.577 & 23.781 & 48.358 \\
\hline 31 & Sambi Kerep & 30.126 & 29.620 & 59.746 \\
\hline & Jumlah & 1.566 .072 & 1.559 .504 & 3.125 .576 \\
\hline
\end{tabular}

Sumber: Data Diolah dari Dinas Kependudukan dan Catatan Sipil, 2013,

Berdasarkan data dari Dinas Kependudukan dan Catatan Sipil Kota Surabaya, komposisi penduduk Kota Surabaya pada tahun 2012 berdasarkan kelompok usia dapat dijelaskan bahwa proporsi terbanyak adalah pada kelompok usia 15 sampai dengan 64 tahun (2.250.805 jiwa) selanjutnya kelompok usia kurang dari 15 tahun (684.385 jiwa) dan kelompok usia diatas 64 tahun (190.386 jiwa. Komposisi penduduk kota Surabaya pada tahun 2012 berdasarkan jenis pekerjaan dapat dijelaskan bahwa penduduk kota Surabaya pada umumnya bekerja sebagai karyawan swasta yaitu sebanyak 880.945 jiwa. Komposisi penduduk berdasarkan tingkat pendidikan dapat dijelaskan bahwa tingkat pendidikan terbesar penduduk kota Surabaya adalah SMA/sederajat sebanyak 947.216 jiwa, kemudian Sekolah Dasar (SD)/sederajat sebanyak 620.394 jiwa dan lulus Sekolah Menengah Pertama (SMP) sebanyak 428.521 jiwa.

Dengan demikian dapat disimpulkan bahwa penduduk usia 15 sampai 64 tahun merupakan individu-individu yang aktif berkarya, baik di usia tertentu mereka belajar, bekerja, dan berwirausaha. Usia tersebut merupakan usia yang aktif bekerja dan mempunyai target kehidupan, seperti karir, menikah, dan kepemilikan tempat tinggal. Oleh karena di usia tersebut jumlah penduduknya terhitung cukup besar, maka tuntutan untuk memiliki tempat tinggal sangat banyak yang dipengaruhi oleh tuntutan hidup. Sejalan dengan hal tersebut, pemerintah kota Surabaya memberikan kebijakan publik dimana pembangunan perumahan sangat dicari oleh individu di masa usia tersebut. Salah satu kawasan yang sedang berkembang di kota Surabaya 
adalah Surabaya timur dimana terdapat berbagai institusi, Universitas, Sekolah, dan perusahaan yang berdiri di area ini. Beberapa rusun dan apartemen telah dibangun untuk memenuhi kebutuhan akan tempat tinggal.

Efektifitas kebijakan publik dapat diukur dari berapa besar kebijakan tersebut dapat diaplikasikan dan memberi jalan keluar terhadap berbagai masalah publik yang sedang terjadi saat ini. Hal ini berarti bahwa pelayanan publik adalah kegiatan tindak lanjut dari penerapan kebijakan yang langsung bersentuhan dengan masalah dan kepentingan masyarakat (Rusli, 2013). Untuk mencapai efektifitas suatu kebijakan publik, maka pemerintah perlu mewujudkan kebijakan yang baik dan benar atau yang melayani masyarakat. Kebijakan tersebut perlu memperhatikan beberapa hal sebagai berikut:

\section{Melibatkan publik dalam segala tahap}

Pelibatan publik dalam kebijakan public dalam segala tahap (perencanaan, implementasi, dan evaluasi) dibutuhkan agar kebijakan tersebut benar -benar sesuai dengan kebutuhan publik. Seringkali hanya pada perencanaan saja publik dilibatkan. Hasilnya memang kebijakan tersebut ditujukan untuk publik tetapi karena dalam implemntasi dan evaluasi publik tidak dilibatkan maka bisa saja implementasinya tidak sesuai atau kalau sesuaipun tidak diikuti oleh partisipasi publik yang memadai. Dalam evaluasipun publik perlu dilibatkan supaya bisa memberi masukan pada kebijakan berikutnya agar lebih sempurna. Undang-undang tentang Pemerintah Daerah memberikan peluang bagi partisipasi publik dalam kebijakan publik yaitu mimungkinkannya dibentuk forum pemangku kepentingan (stakeholders) kota atau kabupaten yang anggota - anggotanya terdiri dari berbagai pihak dan unsur masyarakat. Meskipun ada forum seperti itu, partisipasi langsung masyarakat misalnya lewat kotak pengaduan seharusnya juga dibuka.

\section{Realistik}

Kebijakan publik yang baik juga harus realistik. Realistik dalam arti kebijakan tersebut harus benar -benar bisa diterapkan dan dengan mempertimbangkan kemampuan dari pihak pemerintah baik dalam hal organisasi, personalia, maupun keuangan. 


\section{Transparan}

Transparansi kebijakan yang dimaksud adalah publik harus bisa mengakses informasi yang terkait dengan kebijakan. Hal krusial dalam kebijakan publik yang menuntut transparansi adalah masalah keuangan. Dalam ketentuan undang - undang sekarang ini sudah diharuskan APBD baik propinsi maupun kota dan kabupaten untuk memakai format yang transparan dan dapat di pertanggungjawabkan antara lain karena jelas tujuan penggunaannya, jelas dasar perhitungannya dan jelas tolok ukur dampak dari alokasi anggaran tersebut.

\section{Jelas Tolok Ukur Keberhasilannya}

Kebijakan yang baik juga harus jelas tolok ukur keberhasilannya. Hal ini berguna untuk digunakan sebagai alat atau instrumen untuk melakukan evaluasi

\section{Jelas Target atau Sasarannya}

Kebijakan yang baik juga harus tepat sasarannya. Misalnya kebijakan pengentasan kemiskinan harus jelas kriteria siapa yang dimaksud sebagai orang miskin itu. Jangan sampai karena definisi operasional target yang tidak jelas maka kebijakan yang dilaksanakan menjadi tidak tepat sasaran atau targetnya.

\section{Jelas Dasar Hukumnya}

Kebijakan publik yang dilaksanakan oleh pemerintah juga harus jelas dasar hukumnya karena kebijakan tersebut tidak dilaksanakan di ruang hampa udara. Memilih landasan hukum yang tepat untuk suatu kebijakan memang bukan hal mudah. Contoh kasus dari tidak berjalannya pilihan dasar hukum yang tepat ini adalah berbagai peraturan daerah (Perda) yang bermasalah akhir-akhir ini . Perdaperda tersebut bermasalah karena: tidak jelas peraturan diatasnya yang menjadi payung, tidak ada peraturan di atasnya yang memayungi, bertentangan dengan perturan di atasnya, dan lain-lain.

7. Antar Kebijakan Tidak Tumpang Tindih dan Bertentangan 
Seringkali terjadi dalam praktek kebijakan terjadi tumpang tindih antar kebijakan dan juga terjadi pertentangan antar kebijakan publik. Tumpang tindih maksudnya adalah apa yang sudah dijangkau oleh suatu kebijakan diatur lagi oleh kebijakan lain. Misalnya saja kasus pembinaan pengusaha kecil. Hampir semua dinas dan lembaga mempunyai program pembinaan untuk pengusaha kecil. Akibatnya ada pengusaha kecil yang berkali-kali harus ikut pembinaan yang dilaksanakan oleh berbagai lembaga dengan materi yang sama. Sedangkan contoh kebijakan yang bertentangan satu sama lain misalnya dulu pernah terjadi kebijakan umum APBD yang nantinya akan menjadi dasar APBD di peraturan yang satu cukup ditetapkan dengan Surat Keputusan bupati atau walikota , tetapi di peraturan yang lain harus dengan Peraturan Daerah (berarti harus disetujui oleh DPRD).

\section{Metodologi}

Data: Adapun pengambilan data berupa observasi dan analisis kebijakan dari Pemerintah kota Surabaya digunakan sebagai bahan untuk meneliti sejauh mana efektifitas kebijakan Pemerintah menyusun keputusan sebagai suatu kebijakan publik yang memperhatikan lingkungan dan pelaku. Data yang diambil dari pembangunan rusun dan apartemen yang ada di Surabaya Timur.

Prosedur :Sistem yang digunakan untuk mengukur efektifitas kebijakan Pemerintah terkait dengan pembangunan rusunawa dan apartemen di wilayah Surabaya Timur yaitu:

(1). Melibatkan publik dalam segala tahap

(2). Realistik

(3). Transparan

(4). Jelas Tolok Ukur Keberhasilannya

(5). Jelas Target atau Sasarannya

(6). Jelas Dasar Hukumnya

(7). Antar Kebijakan Tidak Tumpang Tindih dan Bertentangan

Tujuh tolak ukur diatas menjadi sistem pengukuran efektifitas kebijakan Pemerintah kota Surabaya dalam menagani masalah pengaturan tempat tinggal warga, sehingga terdapat kebijakan yang baik dan benar. 


\section{Hasil}

Konsepsi pengembangan kualitas lingkungan permukiman perkotaan di Kota Surabaya bertujuan untuk melakukan penataan perumahan dan pemukiman di perkotaan dan mengurangi kekumuhan di kawasan berpenduduk padat. Program perumahan dan permukiman diarahkan untuk mengatasi permasalahan Masyarakat Berpenghasilan Rendah (MBR) agar mendapat manfaat rumah layak huni. Pembangunan di bidang perumahan dan permukiman tidak hanya membangun perumahan atau permukiman baru, akan tetapi juga menjaga kualitas sarana prasarana permukiman itu menjadi lebih baik, lebih sehat dan tidak kumuh. Penanganan permukiman kumuh yang dilaksanakan oleh Pemerintah Kota Surabaya dilaksanakan secara multisektoral melalui upaya pembenahan fisik dan lingkungan serta pemberdayaan masyarakat. Pengembangan hunian diarahkan secara vertikal untuk mengatasi keterbatasan lahan. Berdasarkan data Dinas Pekerjaan Umum Bina Marga dan Pematusan Kota Surabaya, luasan kawasan kumuh di Kota Surabaya mencapai 329,1 Ha atau 1,01\% dari luas wilayah kota. Pemerintah Kota Surabaya juga mengupayakan penyediaan lahan bagi terbangunnya rumah sederhana layak huni yang memiliki konsep pembangunan vertical dengan dukungan dana dari Pemerintah Pusat maupun Pemerintah Provinsi yang diperuntukkan bagi MBR di Kota Surabaya agar bisa mendapatkan manfaat rumah layak huni. Sampai dengan tahun 2012, di Kota Surabaya terdapat 11 lokasi Rumah Susun (Rusun) yang terdiri dari 70 blok rusun yang dikelola oleh Pemerintah Kota Surabaya, yaitu Rusun Dupak Bangunrejo, Rusun Sombo, Rusun Urip Sumoharjo, Rusun Penjaringan Sari I, II dan III, Rusun Wonorejo I dan II, Rusun arugunung, Rusun Tanah Merah I dan II, Rusun Randu, Rusun Jambangan, Rusun Pesapen dan Rusun Grudo. Selain mengupayakan konsep pembangunan rumah sederhana layak huni vertikal, Pemerintah Kota Surabaya mengupayakan pembangunan, perbaikan dan pemeliharaan sarana prasarana di lingkungan permukiman kumuh/tidak layak huni melalui kegiatan rutin antara lain pembangunan dan pemeliharaan sarana prasarana permukiman, peningkatan pemanfaatan dan pengelolaan rumah susun sederhana sewa serta pemeliharaan dan pengadaan sarana dan prasarana makam. Selain itu, pembangunan apartemen di berbagai wilayah kota Surabaya telah memberikan 
dampak positif bagi penambahan devisa Negara karena pelaksanaan bisnis atau perdagangan dapat diwujudkan. Beberapa contoh apartemen yang memiliki tujuan kelayakan tempat tinggal dan bisnis center yaitu Gunawangsa, Bale Hinggil, dan Puncak Kertajaya

Surabaya merupakan kota dengan pertumbuhan ekonomi yang tinggi. Beberapa perusahaan besar memiliki kantor pusat di dan di sekitar Surabaya. Karena perkembangan ekonomi yang pesat maka kota Surabaya merupakan lokasi yang menarik bagi para investor yang berasal dari Indonesia bagian timur untuk melakukan investasi property. Seperti Jakarta, siklus properti di Surabaya yang terpengaruh selama krisis keuangan Asia tahun 1997 dan krisis keuangan global pada tahun 2008, akan tetapi sejak itu, pasar properti di wilayah ini telah mempertahankan tren pengembangan property yang optimis, terutama perkembangan property hunian seperti apartemen. Untuk melihat trend pengembangan apartemen dapat dilihat pada table research Collier International Indonesia yang berada di bawah ini:

Tabel 2 Research Collier

\section{CUMULATIVE SUPPLY OF APARTMENTS FOR STRATA-TITLE IN SURABAYA}

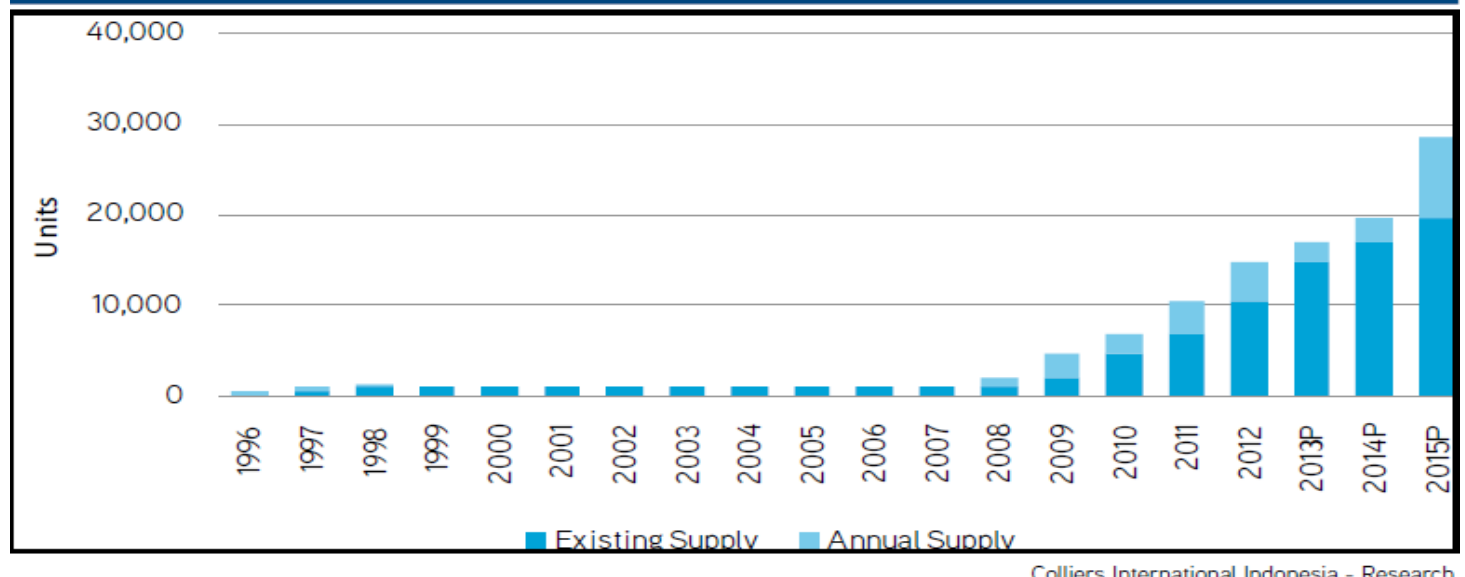

Tingginya kebutuhan akan apartemen di pusat kota seperti Surabaya, juga disebabkan karena harga tanah yang semakin meningkat dari waktu ke waktu. Kondisi ini menunjukan harga tanah semakin tinggi. Landed house di Surabaya akan semakin mahal. Saat ini sulit sekali untuk memperoleh rumah di bawah Rp 200 juta/unit. Setidaknya terdapat 15 apartemen yang ada di Surabaya. Surabaya Barat 
paling diminati pengembang apartemen. Di kawasan itu terdapat antara lain berdiri The Via \& The Vue di kawasan Ciputra World yang memiliki 400 unit apartemen. Kemudian dua menara milik PT Adhibaladika Agung di kawasan Bukit Darmo Golf dengan The Adiwangsa sebanyak 372 unit. Ada juga tiga Menara Metropolis sebanyak 800 unit apartemen di J1 Tenggilis dan Apartemen Kosmopolis dengan 180 unit dibangun PT Kreativitas Putra Mandiri. Sedangkan untuk perkembangannya, pada tahun 2014 dan 2015 terdapat 11 pembangunan apartemen baru di kota Surabaya, untuk lebih jelasnya dapat dilihat pada tabel dibawah ini :

Tabel 3

Pembangunan Apartemen di Surabaya

\begin{tabular}{|c|c|c|c|}
\hline 2014 & & $\mathbf{r}^{--}$ & 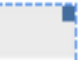 \\
\hline The Peak Residence & Jl. Basuki Rahmat & Pakuwon Group & 190 \\
\hline Orchard Mansion & Pakuwon Indah & Pakuwon Group & 940 \\
\hline De Papillio Tamansari & J. Ahmad Yani & Wika Realty & 446 \\
\hline Tanglin Mansion & Pakuwon Indah & Pakuwon Group & 940 \\
\hline \multicolumn{4}{|l|}{2015} \\
\hline Bale Hinggil Apartment & J. Ir. Soekarno & PT Tlatah Gema Anugrah & 2.014 \\
\hline Puncak Dharmahusada & J. Ir. Soekarno & Puncak Group & 1,250 \\
\hline Puncak Bukit Golf & J. Raya Bukit Darmo Boulevard I & Puncak Group & 1.250 \\
\hline Voila Apartment & J. Mayjen Sungkono & Ciputra Group & 216 \\
\hline Ritz Mansion & Pakuwon Indah & Pakuwon Group & 450 \\
\hline Linden Tower & J. Ngagel 123 & Consortium Kencana Group, PT Dian Istana and PT Avila Prima & 360 \\
\hline Educity Apartment & J. Kejawan Putih Mutiara No. 17 & Pakuwon Group & 3,600 \\
\hline
\end{tabular}

Sumber: Collier International Indonesia

Berdasarkan data konsultan properti Colliers International, pada tahun 2013 Surabaya berhasil mensuplai lebih dari 16 ribu unit apartemen. Menurut Associate Directors Colliers International Ferry Salanto, yang mendorong peningkatan apartemen di Surabaya adalah banyaknya jumlah kampus di kota ini. Pertumbuhan apartemen di Surabaya ini didorong oleh jumlah kampus di Surabaya, terutama di sebelah timur Surabaya, sehingga konsentrasi pembangunan apartemen ke depannya akan dipusatkan di Surabaya Timur.

\section{Pembahasan}


Sesuai dengan hasil pembahasan data analisis maka pembangunan rusun di berbagai tempat di kota Surabaya merupakan kebijakan Pemerintah yang tertuang dalam Peraturan Walikota Surabaya Nomor 46 Tahun 2013 Tentang Rencana Kerja Pembangunan Daerah (RKPD) Kota Surabaya Tahun 2014. Kebijakan ini telah memenuhi tujuh tolak ukur untuk menuju efektifitas Kebijakan Publik, yaitu:

1. Melibatkan publik dalam segala tahap

Dalam penyusunan keputusan kebijakan, pemerintah telah memperhatikan jumlah penduduk kota Surabaya yang semakin meningkat, terutama jumlah usia 1564 tahun yang mana usia tersebut merupakan usia yang produktif bekerja dan membutuhkan kelayakan tempat tinggal, sehingga dengan adanya pembangunan rusun dan apartemen dipandang sebagai keputusan yang melibatkan segala tahap.

2. Realistik

Kebijakan ini dipandang sebagai keputusan yang realistik karena dari segi organisasi perusahaan melihat bahwa pemanfaatan lahan tanah untuk rusun dan apartemen sangat efisien.

3. Transparan

Transparansi kebijakan yang dimaksud adalah publik harus bisa mengakses informasi yang terkait dengan kebijakan. Hal krusial dalam kebijakan publik yang menuntut transparansi adalah masalah keuangan. Dalam ketentuan undang - undang sekarang ini sudah diharuskan APBD baik propinsi maupun kota dan kabupaten untuk memakai format yang transparan dan dapat di pertanggungjawabkan antara lain karena jelas tujuan penggunaannya, jelas dasar perhitungannya dan jelas tolok ukur dampak dari alokasi anggaran tersebut.

\section{Jelas Tolok Ukur Keberhasilannya}

Pembangunan rusun dan apartemen telah memberikan dampk positif bagi masyarakat dan pemerintah. Terutama bagi masyarakat, pihak-pihak yang bertempat tinggal di rusun yaitu masyarakat ekonomi bawah, memandang bahwa hal ini sangat menguntungkan karena dari segi ekonomi memberikan solusi tempat tinggal yang layak dengan harga yang terjangkau, sedangkan bagi masyarakat ekonomi menengah keatas memandang bahwa pembangunan apartemen sangat memberikan keuntungan karena keterjangkauan menuju wilayah satu ke wilayah yang lain. 


\section{Jelas Target atau Sasarannya}

Kebijakan pemerintah dalam pembangunan rusun dan apartemen memiliki target dalam penataan dan pengaturan masyarakat yang merata. Pemerintah menargetkan masyarakat ekonomi bawah memiliki tempat tinggal yang layak di Rumah Rusun sedangkan masyarakat ekonomi menengah keatas memiliki kelayakan tempat tinggal di apartemen.

\section{Jelas Dasar Hukumnya}

Pembangunan apartemen sebagai salah satu contoh yang mana pemerintah dengan mudah memberikan legalitas kepemilikan apartemen dengan pengurusan IMB.

7. Antar Kebijakan Tidak Tumpang Tindih dan Bertentangan.

Kebijakan pembangunan rusun telah diatur dan dikelola dengan baik oleh pemerintah dengan menggandeng pihak swasta sebagai pelaku pembangunan, sedangkan

\section{Kesimpulan.}

Kota Surabaya memiliki penduduk yang sangat produktif. Produktifitas masyarakat ini telah berperan aktif dalam penyusunan kebijakan pemerintahan Kota Surabaya. Seperti halnya mengenai masalah pengaturan lahan dan pemukiman, pemerintah merencanakan dan mengantisipasi melalui beberapa kebijakan sehingga jumlah penduduk yang semakin meningkat ini dapat diatur dan diberikan sarana dan prasarana yang layak dan merata. Salah satu masalah yang dihadapi adalah jumlah penduduk yang meningkat dengan tuntutan kepemilikan tempat tinggal yang layak. Solusi dari permasalahan tersebut, maka dibangun rusun dan apartemen di Kota Surabaya sebagai salah satu wujud kebijakan pemerintah sesuai yang dituangkan dalam Peraturan Walikota Surabaya Nomor 46 Tahun 2013 Tentang Rencana Kerja Pembangunan Daerah (RKPD) Kota Surabaya Tahun 2014. Kebijakan ini memiliki efektifitas karena memperhatikan pihak-pihak yang terkait seperti pelaku yaitu masyarakat dan lingkungan. Pembangunan ini dipandang sebagai kebijakan yang 
melibatkan publik dalam segala tahap, realistic, transparan, jelas tolak ukrnya, jelas target atau sasarannya, jelas dasar hukumnya, dan kebijakan yang tidak tumpang tindih. Dengan adanya pembangunan rusun dan apartemen, masyarakat lebih terjamin kehidupannya di masa kini dan masa yang akan datang.

\section{Daftar Pustaka}

Taufik, B. 2002. Mikro Ekonomi untuk Kebijakan Publik. Edisi pertama. Jakarta: Pustaka Petronomika.

Rusli, B. 2013. Kebijakan Publik. Membangun Pelayanan Publik Yang Responsif. Bandung: Hakim Publishing.

William N. Dunn. 2003. Pengantar Analisis Kebijakan Publik, Gadjah Mada University Press: Yogyakarta.

Subarsono, A. 2005. “Analisis Kebijakan Publik; Konsep, Teori dan Aplikasi, Yogyakarta: Pustaka Pelajar.

Lampiran 1 Peraturan Menteri Pendayagunaan Aparatur Negara Nomor PER/04/M.PAN/4/2007 tentang Pedoman Umum Formulasi, Implementasi, Evaluasi Kinerja, dan Revisi Kebijakan Publik di Lingkungan Lembaga Pemerintah Pusat dan Daerah

Peraturan Walikota Surabaya Nomor 46 Tahun 2013 Tentang Rencana Kerja Pembangunan Daerah (RKPD) Kota Surabaya Tahun 2014. 